\title{
THE EXAMINATION OF MEASUREMENT INVARIANCE OF MOTIVATIONS TO BECOME A TEACHER SCALE IN TERMS OF DEPARTMENT AND GENDER
}

\author{
Serhat Aydin', Murat İbrahim Yazar ${ }^{2}$ \\ ${ }^{1}$ Department of Mathematics and Science, Karamanoğlu Mehmetbey University, Karaman, Turkey \\ ${ }^{2}$ Department of Mathematics and Science, Karamanoğlu Mehmetbey University, Karaman, Turkey
}

\begin{abstract}
Measurement instruments used in psychology or education are expected to work similarly in different groups in order to make meaningful comparisons and assessments across these groups. This issue is handled via conducting measurement invariance (MI) tests on data collecting tools. Usually only a single parameter is addressed in MI studies and one of the most frequently examined parameter is gender. In Turkey, measurement invariance studies are still limited in number and they concentrate also on the gender variable. In this study, factor structure of 9-items Motivations to Become a Teacher Scale developed for international Teacher Education and Development Study in Mathematics (TEDS-M) and measurement invariance of these factors in terms of department and gender were examined. For this aim, the 5-stage method recommended by Vandenberg and Lance was used. This method is based on the progressive application of different models from the least restricted through the most restricted one. The study sample consisted of 1878 preservice teachers from four different departments from 16 different universities randomly selected in Turkey. The data was analyzed using multi-group confirmatory factor analysis in Lisrel 8.80 software. In order to determine invariance, several fit indices were used together. According to 5-stage analysis outputs, it was concluded that the scale had two factors such as "intrinsic motivation" and "extrinsic motivation", these factors had measurement invariance in terms of department and gender and the Scale could be used to compare different departments and sexes.
\end{abstract}

Keywords: Motivations to Become a Teacher, Measurement Invariance (MI), Preservice Teachers, Intrinsic Motivation, Extrinsic Motivation

\section{INTRODUCTION}

Motivation has been classically defined as a function of the value placed on certain goals and the perceived likelihood that a behavior will lead to those goals [1]. Although the term has emerged from observation of inner mechanisms of action [2], it's also effected from outer causes, it forces the person to act and is one of the most significant variables in determining why someone behave in a particular way [3]. This deep inner mechanism, which is fueled and controlled by several inner(intrinsic) and outer (extrinsic) factors [4], acts on every decision a human being takes one of which is choosing a profession. The motivation to choose a profession was defined as the orientation of a person to the profession which she/he sees most fulfilling and promising [5]. The motivation to become a teacher might explain how determined, decisive and ambitious someone is to teach. The motivation for becoming a teacher was found related to engagement in and commitment to the profession $[6 ; 7 ; 8]$. Several inner and outer factors are probably effecting this mood.

So far, many studies in EU $[9 ; 10 ; 7 ; 11]$ Australia [12], China [13], US [14] and Turkey [15; 16; 17] were conducted in order to identify the motivations of in-service and preservice teachers to choose the teaching profession. The literature shows that there are basically two latent variable groups acting on these decisions which are intrinsic and extrinsic factors [4]. Intrinsic factors include reasons such as "love for a specific subject", "love for spending time with kids", and extrinsic factors include reasons such as "long term job security" [4; 7].

By identifying the motivations of (preservice teachers) to become a teacher, possible solutions for the retention of teachers in the teaching profession $[18 ; 8]$ might be developed. Identifying and improving teacher motivation might increase job satisfaction [5] and allow teachers improve pupils' motivation [19; 20]. Longitudinal studies might also identify the motivations of the "best achieving" pre-service and in-service teachers in order to make plans to attract more of these to teaching profession [21]. In addition, motivationally advantaged groups in terms of demographic variables might be determined [22].

As mentioned above, many studies have explored the motivation to become a teacher though it was criticized that these studies had used weak methodologies [8] or not provided evidence for the validity of the scales used across different contexts [23]. Motivations to become a teacher should be compared across groups, but to be able to make meaningful comparisons, the measurement instruments should have construct validity. Construct validity of a 
measurement instrument means that it really measures the construct it is intended to. Construct validation is the basic prerequisite to the proper interpretation of a test score [24]. However, successfully measuring the construct in the entire sample doesn't even suffice that the construct will measure the construct in homogenous subgroups such as females successfully. This concept is defined as measurement invariance and is needed to be able to compare these groups meaningfully [25] but usually is not tested [26]. The number of studies on the measurement invariance of instruments are scarce [27] and no studies were encountered yet on the MI of scales measuring motivations to become a teacher. At this point, TEDS-M Intentions/Motivation to be a teacher" scale [21] which was adapted from English into Turkish and shown to be valid and reliable (total variance explained by the whole scale $=\%$ 50, alpha $=0.75$ Mc Donald Omega $=$ 0.85 , item-total correlations above 0.54 ) is an important and robust measurement instrument [28]. The original scale and its Turkish form has nine items, three of which are related to extrinsic reasons and the remaining six are related to intrinsic reasons. The original scale was used in international comparative study Teacher Education and Development Study in Mathematics (TEDS-M) in 17 countries on more than 8000 preservice teachers [21].

Based on the literature mentioned above research questions of this study were posed as follows:

1. Does the Turkish adaptation (of TEDS-M Motivations to Become a Teacher Scale have measurement invariance across different departments?

2. Does the Turkish adaptation of TEDS-M Motivations to Become a Teacher Scale have measurement invariance across different genders?

\section{METHOD}

In this part, the study sample, instruments and data analysis procedures are explained.

\subsection{Study Sample}

The study sample consisted of 1878 preservice teachers from 16 different universities randomly selected in Turkey. It is illustrated in Table 1.

Table -1: Study Sample

\begin{tabular}{|l|l|l|l|}
\hline Variable & $\begin{array}{l}\text { Variable } \\
\text { Levels }\end{array}$ & Frequency & $\begin{array}{l}\text { Percentage } \\
(\%)\end{array}$ \\
\hline Gender & Female & 1446 & 77,0 \\
\hline & Male & 432 & 23,0 \\
\hline Year of study & $1^{\text {st }}$ Year & 1364 & 72,6 \\
\hline & $2^{\text {nd }}$ Year & 176 & 9,3 \\
\hline & $3^{\text {rd }}$ Year & 187 & 9,9 \\
\hline & $4^{\text {th }}$ Year & 151 & 8,0 \\
\hline Department & Preschool & 216 & 11,5 \\
\hline & Primary & 624 & 33,2 \\
\hline & $\begin{array}{l}\text { Elementary } \\
\text { Maths }\end{array}$ & 917 & 48,8 \\
\hline & $\begin{array}{l}\text { Secondary } \\
\text { Maths }\end{array}$ & 121 & 6,4 \\
\hline & Total & 1878 & 100 \\
\hline
\end{tabular}

Table 1 illustrates that the study sample consisted of 1446 (\% 77) female and 432 (\% 23) male preservice teachers. In terms of year of study, $1364(\% 72,6)$ are 1st years (Freshmen), 176 (\% 9,3) are 2nd years (Sophomores), 187 $(\% 9,9)$ are 3 rd years (Juniors) and $151(\% 8,0)$ are 4 th years (Seniors). In terms of department, 216 (\% 11,5) are in preschool education, $624(\% 33,2)$ are in primary education, $917(\% 48,8)$ are in elementary mathematics education and $121(\%, 6,4)$ are in secondary mathematics education department.

\subsection{Instruments}

In this study, factor structure of the Turkish form of 9-items Motivations to Become a Teacher Scale developed for international Teacher Education and Development Study in Mathematics (TEDS-M) [21] and measurement invariance of this factor structure in terms of department and gender was explored. The original scale was reported to have two factors such as "intrinsic motivation" (6 items) and "extrinsic motivation" (3 items). The Turkish adaptation of the scale was also reported to have the same two factors and alpha coefficients above ,74 for both factors and the whole scale [28].

\subsection{Data Analysis}

First of it was checked whether the dataset met the assumptions of multi-group confirmatory factor analysis method (MGCFA). For this aim, the five-stage method such as i) seperate CFAs for each level of variables, ii) configural invariance test, iii) weak (metric) invariance test, iv) strong (scaler) invariance test and v) complete (strict) invariance test was used [29]. The tests were conducted hierarchically and step by step. The scale was accepted to have measurement invariance for a variable if and only if it had passed these five tests.

\section{FINDINGS}

In this part of the study, the findings of the study are presented. Firstly, 13 missing values and 25 outliers (z-score smaller than -3 or larger than 3 ) were removed from the study. Then, normality assumption was tested for all 9 items. Skewness and kurtosis values between -1 and 1 were taken as evidence that an item met the assumption of normality [30]. Table 2 shows the skewness and kurtosis values for all items. 
Table - 2: Findings of skewness and kurtosis tests for all items across subgroups

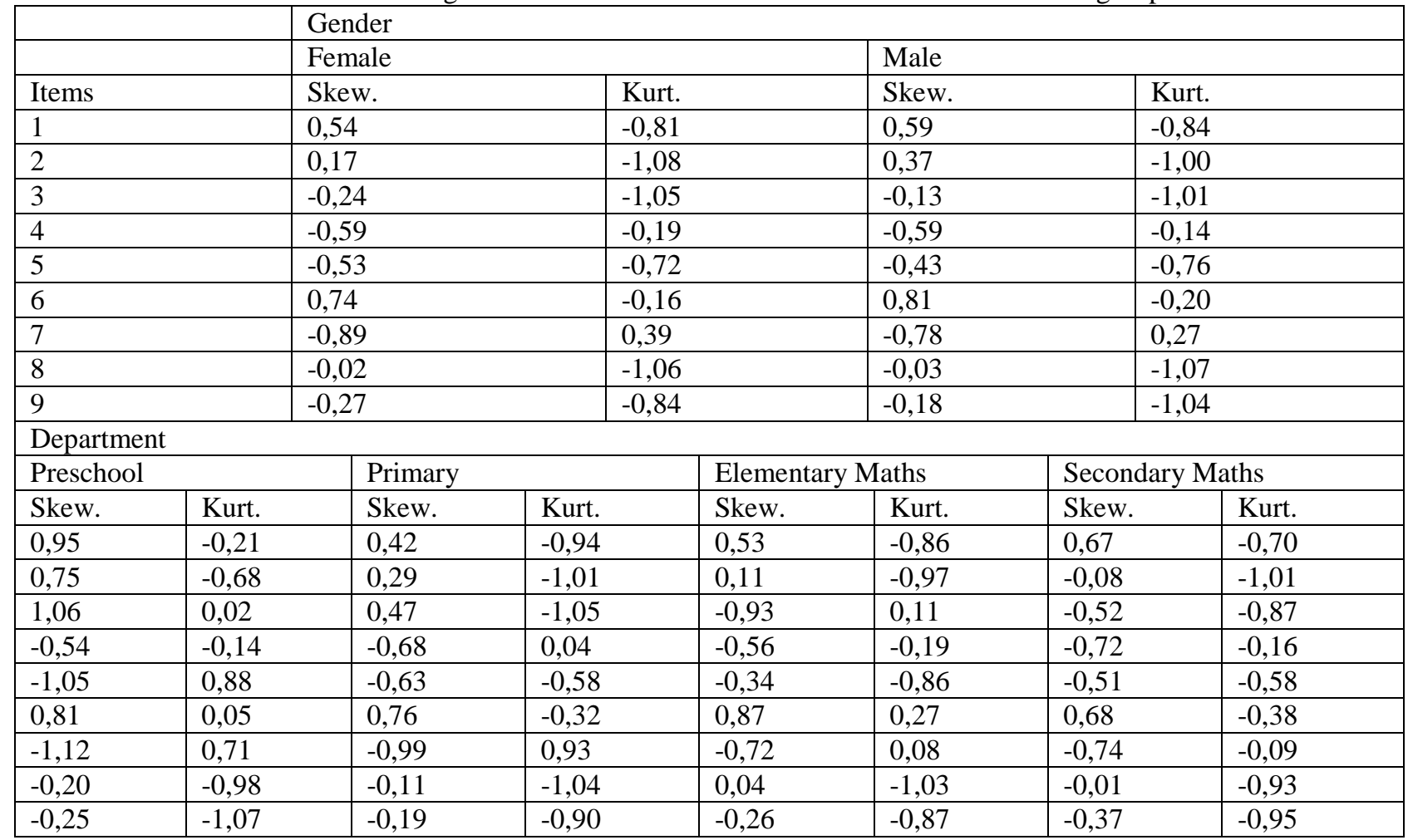

The skewness and kurtosis values for the items shown Table 2 provides evidence that the normality assumption was met for the data at hand. Then a preliminary CFA was conducted to test find out how much the 9-item model provided a good fit. The results of the preliminary CFA on 9-item two-factor model is shown in Figure 1.

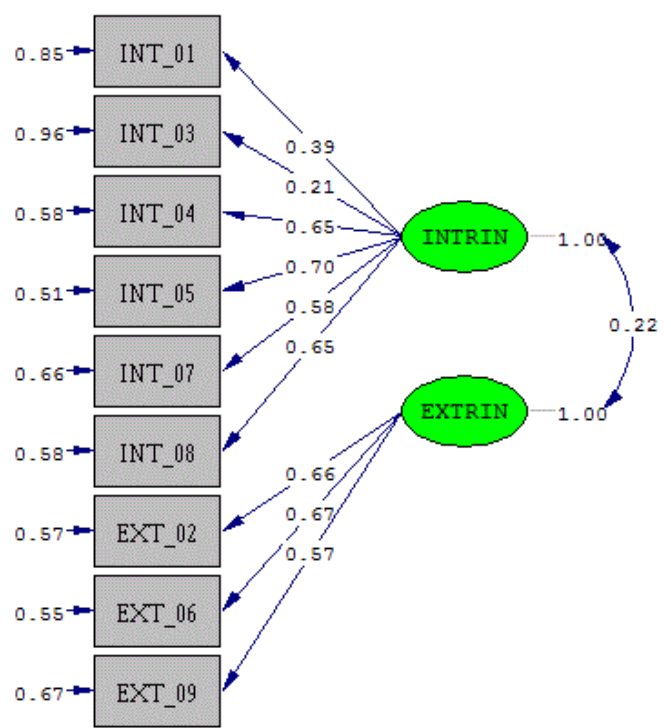

Fig -1: Preliminary CFA findings of 9-item bidimensional model tested on the entire sample

The preliminary CFA findings of 9-item bidimensional model tested on the entire sample did not provide a good fit $(\chi 2(\mathrm{df})=500(26), \rho<, 000$, RMSEA $[90 \% \mathrm{CI}]=, 142$ $[, 13 ;, 15], \quad \mathrm{SRMR}=13, \mathrm{NNFI}=, 71)$. This lack of fit was thought to be stemming mainly from item INT_03. This item reads "I want to be a teacher because I like mathematics" which is rather relevant to preservice elementary and secondary mathematics teachers but not to preservice primary or preschool teachers. So this item was excluded from the analysis which led to 8-item bidimensional baseline model which reveled acceptable fit indices $(\chi 2(\mathrm{df})=72(26), \rho<, 000$, RMSEA [90\% CI] $=, 07$ $[, 07 ;, 07], \mathrm{SRMR}=, 06, \mathrm{NNFI}=, 93)$. The baseline model is illustrated in Figure 2.

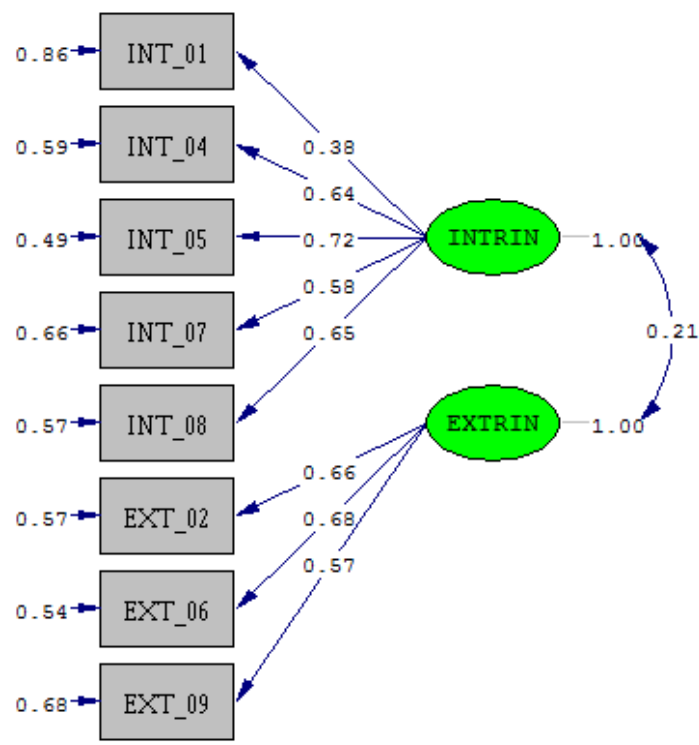

Fig - 2: Adjusted baseline model of 8-item bidimensional model tested on the entire sample 
Then the hypothesized baseline model shown in Figure 2 was tested across subgroups within gender and department variables. The first item in each factor (dimension) of the scale was fixed to 1 as reference. The findings of separate CFA tests on each subgroup is presented in Table 3.

Table - 3: Fit indices for the baseline model in subgroups

\begin{tabular}{|c|c|c|c|c|c|c|c|}
\hline Groups & Subgroups & $\begin{array}{l}\chi^{2} \\
\text { (df) }\end{array}$ & $\begin{array}{l}\text { RMSEA [90\% } \\
\text { CI] }\end{array}$ & SRMR & NNFI & CFI & Decision \\
\hline \multirow[b]{2}{*}{ 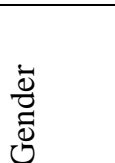 } & Female & $\begin{array}{l}51 \\
(19)\end{array}$ & $.05[.05 ; .06]$ & .05 & .96 & .95 & Accept \\
\hline & Male & $\begin{array}{l}42 \\
(19)\end{array}$ & $.05[.05 ; .05]$ & .05 & .97 & .95 & Accept \\
\hline \multirow{4}{*}{ 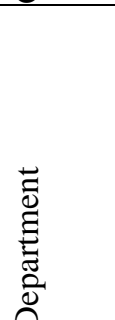 } & Preschool & $\begin{array}{l}27 \\
(19)\end{array}$ & $.04[.04 ; .04]$ & .04 & .98 & .97 & Accept \\
\hline & Primary & $\begin{array}{l}29 \\
(19)\end{array}$ & $.04[.04 ; .05]$ & .05 & .98 & .96 & Accept \\
\hline & Elem. M. & $\begin{array}{l}31 \\
(19)\end{array}$ & $.04[.04 ; .05]$ & .05 & .98 & .96 & Accept \\
\hline & Sec. M. & $\begin{array}{l}30 \\
(19)\end{array}$ & $.04[.04 ; .05]$ & .05 & .98 & .96 & Accept \\
\hline
\end{tabular}

According to the fit indices shown in Table 3, the original baseline model fitted the data for each subgroup separately. After the fit of data to the model for each separate subgroup was shown, one-way ANOVAs for department and t-tests for independent samples for gender groups were conducted. The t-tests indicated no statistically significant variation in responses of males and females. On the other hand, one-way ANOVAs indicated statistically significant variation in responses of preservice teachers from different departments in three items. The findings of ANOVAs and t-tests are shown in Table 4.

Table - 4: Findings of ANOVAs and t-tests for the items

\begin{tabular}{|c|c|c|c|c|c|c|}
\hline & Gender & & & Department & & \\
\hline Item & $\mathrm{t}$ & $\mathrm{df}$ & $\mathrm{p}$ & $\mathrm{F}$ & $\mathrm{p}$ & $\mathrm{df}$ \\
\hline 1_INT &,- 121 & 1870 & ,904 & ,813 & ,487 & 3 \\
\hline 4_INT & 1,453 & 1868 & , 146 & 2,680 &, $045^{*}$ & 3 \\
\hline 5_INT & ,978 & 1864 & ,328 & 2,151 & ,092 & 3 \\
\hline 7_INT & ,970 & 1866 & ,332 & 1,417 & ,236 & 3 \\
\hline 8_INT &,- 347 & 1866 & ,729 & 3,456 &, $016 *$ & 3 \\
\hline 2_EXT & , 402 & 1866 & ,688 & ,640 & ,589 & 3 \\
\hline 6_EXT & $-1,739$ & 1868 & ,082 & ,679 & ,565 & 3 \\
\hline 9_EXT & 1,383 & 1868 &, 167 & 2,750 &, $041 *$ & 3 \\
\hline$* \mathrm{p}<.05$ & & & & & & \\
\hline
\end{tabular}

The statistically significant variations in some items across different departments shown in Table 4 can indicate a real variation of responses in these subgroups. On the other hand, this might also indicate a measurement invariance problem. In order to eliminate this probability, invariance tests should be conducted and comparability of results obtained from this scale should be proven. Findings of measurement invariance tests are shown in Table 5. At the first stage of measurement invariance analysis illustrate in Table 4 the fit of data separately to each subgroup of gender, department and year of study variables were shown. At this point four more stages of analysis were conducted. These tests were conducted from the least restricted model (Configural) to the most restricted one (Strong).

Table - 5: Findings of Measurement Invariance Tests

\begin{tabular}{|c|c|c|c|c|c|c|c|}
\hline & MI & $\begin{array}{l}\chi^{2} \\
(\mathrm{df})\end{array}$ & $\begin{array}{l}\Delta \chi^{2} \\
(\Delta \mathrm{df}) \\
p\end{array}$ & RMSEA $[90 \% \mathrm{CI}]$ & CFI & NNFI & $\begin{array}{l}\text { Comparison } \\
\text { Decison }\end{array}$ \\
\hline$\frac{\overline{\bar{v}}}{\overline{0}}$ & Co. & $\begin{array}{l}50 \\
(38) \\
>.05\end{array}$ & - & $.04(.04 ; .04)$ & .98 & .97 & - Accept \\
\hline
\end{tabular}




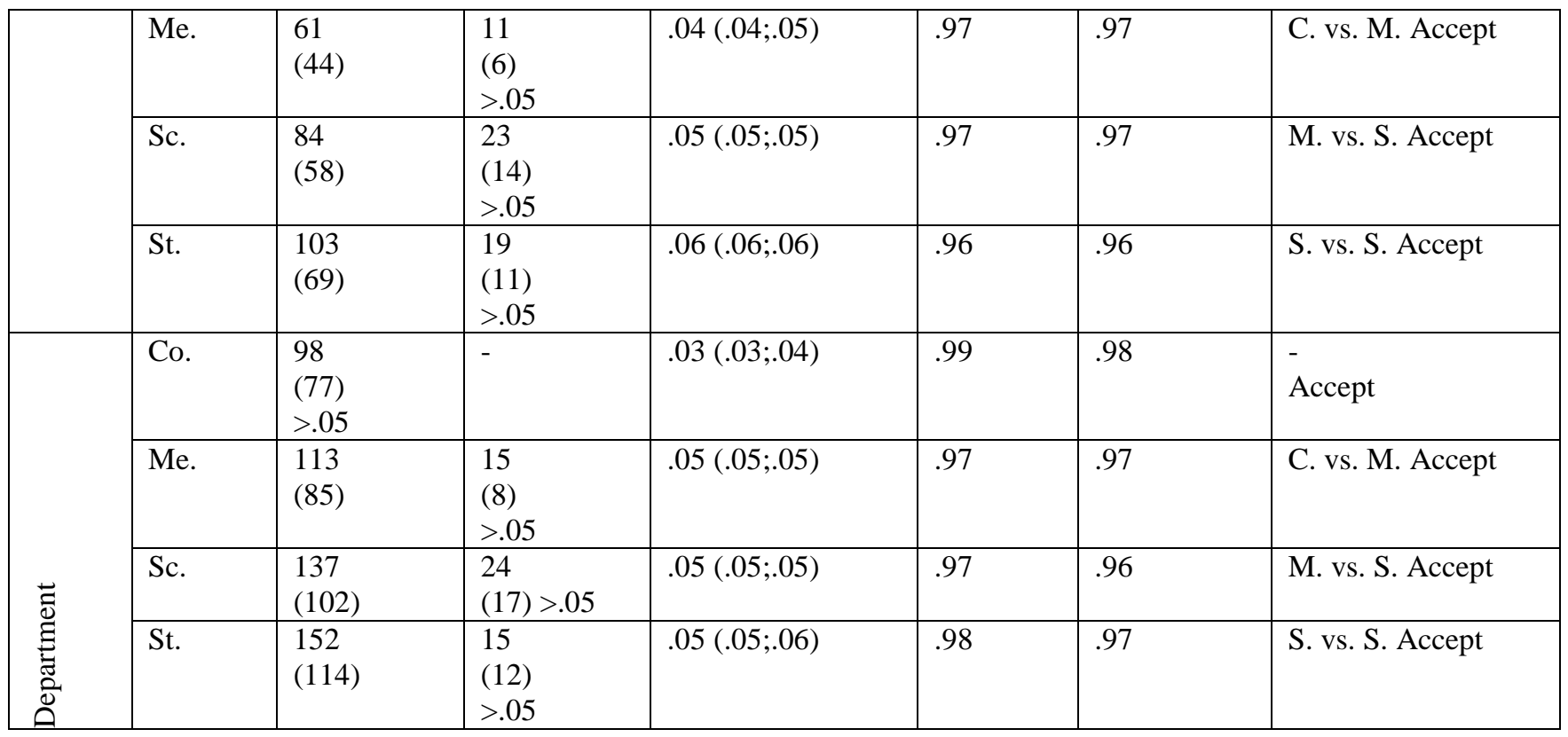

The analyses above in Table 5 support the measurement invariance of the six-factor model across gender and department subgroups. Configural invariance held for both variables respectively (i.e. for gender group $\chi 2=50, \mathrm{df}=38$, $\chi 2 / \mathrm{df}=1.31, \mathrm{p}>.05, \quad \mathrm{RMSEA}=.04 \quad[.04 ; .04], \quad \mathrm{CFI}=.98$, NNFI=.97), indicating two-factor model was acceptable across all subgroups of gender and department. Secondly, metric (weak) invariance was checked by testing equality of factor loadings. When looked at the fit indices, it was found that metric invariance held (i.e. for gender group $\Delta \chi 2=11$, $\Delta \mathrm{df}=6, \mathrm{p}>.05, \mathrm{RMSEA}=.04[.04 ; .05], \mathrm{CFI}=.97, \mathrm{NNFI}=.97)$ and the scale had equal factor loadings across all subgroups of gender and department. Thirdly, according to the fit indices in Table 5, scalar (strong) invariance tests were able to produce non-significant findings (i.e. for gender group $\Delta \chi 2=23, \Delta \mathrm{df}=14, \mathrm{p}>.05, \mathrm{RMSEA}=.04$ [.04;.05], CFI $=.97$, NNFI=.97) for both gender and department variables. Finally, strict (complete) invariance held (i.e. for gender group $\Delta \chi 2=19, \Delta \mathrm{df}=11, \mathrm{p}>.05, \quad \mathrm{RMSEA}=.06 \quad[.06 ; .06]$, $\mathrm{CFI}=.96, \mathrm{NNFI}=.96$ ) across all subgroups of gender and department.

Overall, the findings indicated that measurement invariance held for both variables and a bidimensional 8-item model was tenable. The five-stage model confirmed the separate, configural, weak, strong and complete invariance of the scale across all subgroups of the three variables.

\section{CONCLUSION}

In this study, five-stage model [29] was used to confirm the separate, configural, weak, strong and complete measurement invariance of the Turkish adaptation [28] of TEDS-M Motivations to Become a Teacher Scale [21] across all subgroups of gender and department variables. The results indicated measurement invariance and provided evidence that the scale might be used to compare males and female preservice teachers. According to the results, the scale might also be used to compare preservice teachers from different departments. Previous studies reported that motivations to become a teacher have two dimensions (latent variables or factors) such as intrinsic [31] and extrinsic motivation [32]. These intrinsic and extrinsic motivations were shown to vary significantly across different subgroups of the population both in the world [32] and in Turkey [15; 33]. However, the robustness and measurement invariance of these instruments have not been shown which is being strongly criticized by some researchers [8; 23]. In response, this study was provided evidence for MI and robustness of the Turkish adaptation of the TEDS-M Motivations to Become a Teacher Scale [21] across subgroups of gender and department. This study is in a sense extension of the work by Aydın and Çelik [28] who provided evidence for the validity and reliability of the scale but only for the sample of preservice elementary mathematics teachers which is made up of both males and females. Future research might concentrate on proving MI of the same scale across subgroups of other demographic variables such as year of study or level of general achievement (GPA).

\section{ACKNOWLEDGEMENT}

This study was supported by Karamanoğlu Mehmetbey University, with the project no:23M16.

\section{REFERENCES}

[1] De Jong, G. F., \& Fawcett, J. T. (1981). Motivations for migration: an assessment and a value-expectancy research model.

[2] Maslow, A. H. (1973). Dominance, self-esteem, selfactualization: germinal papers of $\mathrm{AH}$ Maslow. Thomson Brooks/Cole.

[3] Efklides, A., Kuhl, J., \& Sorrentino, R. M. (2001). Trends and prospects in motivation research. Dordrecht; Boston; London: Kluwer Academic. 
[4] Bastick, T. (2000). Why teacher trainees choose the teaching profession: Comparing trainees in metropolitan and developing countries. International Review of Education, 46, 343-349.

[5] Atav, E. ve Altunoğlu, B. D. (2013). Meslek ve alan seçiminde motivasyon ölçeğinin Türkçe formunun geçerlik ve güvenirlik çalışması. Hacettepe Üniversitesi Eğitim Fakültesi Dergisi, 28(2), 58-70.

[6] Fokkens-Bruinsma, M., \& Canrinus, E. T. (2012). Adaptive and maladaptive motives for becoming a teacher. Journal of Education for Teaching, 38, 3-19.

[7] Roness, D., \& Smith, K. (2010). Stability in motivation during teacher education. Journal of Education for Teaching, 36, 169-185.

[8] Sinclair, C., Dowson, M., \& McInerney, D. M. (2006). Motivations to teach: Psychometric perspectives across the first semester of teacher education. Teachers College Record, 108, 11321154.

[9] Berger, J.-L., \& D’Ascoli, Y. (2012). Motivations to become vocational education and training educator: A person-oriented approach. Vocations \& Learning, 5, 225-249.

[10] Roness, D., \& Smith, K. (2009). Post graduate certificate in education (PGCE) and student motivation. European Journal of Teacher Education, 32, 111-135.

[11] Bruinsma, M., \& Jansen, E. P. W. A. (2010). Is the motivation to become a teacher related to preservice teachers' intentions to remain in the profession? European Journal of Teacher Education, 33, 185-200.

[12] Spittle, M., Jackson, K., \& Casey, M. (2009). Applying self-determination theory to understand the motivation for becoming a physical education teacher. Teaching and Teacher Education, 25, 190197.

[13] Lin, E., Shi, Q., Wang, J., Zhang, S., \& Hui, L. (2012). Initial motivations for teaching: comparison between preservice teachers in the United States and China. Asia-Pacific Journal of Teacher Education, 40, 227-248.

[14] Smith, S. J., \& Pantana, J. J. (2010). Preservice second-career teachers in a blended online-residential preparation program: profiling characteristics and motivations (TEJ). Faculty Publications and Presentations. Paper 143 Retrieved from: http://digitalcommons.liberty.edu/educ_fac_pubs/143

[15] Çermik, H., Doğan, B. ve Şahin, A., (2010). Sınıf Öğretmenliği Öğretmen Adaylarının Öğretmenlik Mesleğini Tercih Sebepleri. Pamukkale Üniversitesi Eğitim Fakültesi Dergisi, 28 (2), ss. 201-212.

[16] Eren, A., \& Tezel, K. V. (2010). Factors influencing teaching choice, professional plans about teaching, and future time perspective: A mediational analysis. Teaching and Teacher Education, 26, 1416-1428.

[17] Şeker, H., Deniz, S., \& Gorgen, I. (2015). Pre-service teachers motivations toward teaching profession and their opinions about the pedagogic formation program. Educational Research and Reviews, 10(10), 1403-1414.

[18] Ministry of Education, Culture and Science. (2007). LeerKracht. Advies van de Commissie Leerkracht [Teachers. Advise by the Commission Teachers.]. Den Haag: DeltaHage.

[19] Atkinson, E. S. (2000). An investigation into the relationship between teacher motivation and pupil motivation. Educational Psychology, 1, 45-57.

[20] Lam, S.-F., Cheng, R. W., \& Ma, W. Y. (2009). Teacher and student motivation in project-based learning. Instructional Science, 37, 565-657.

[21] Tatto, M. T., Ingvarson, L., Schwille, J., Peck, R., Senk, S. L. and Rowley, G. (2008). Teacher education and development study in mathematics (TEDS-M): Policy, Practice, and readiness to teach primary and secondary mathematics. Conceptual framework. International Association for the Evaluation of Educational Achievement. Herengracht 487, Amsterdam, 1017 BT, The Netherlands.

[22] Neves de Jesus, S., \& Lens, W. (2005). An integrated model for the study of teacher motivation. Applied Psychology, 54, 119-134.

[23] Watt, H. M. G., \& Richardson, P. W. (2012). An introduction to teaching motivations in different countries: Comparisons using the FIT-Choice scale. Asia-Pacific Journal of Teacher Education, 40, 185197.

[24] Rock, D. A., \& Werts, C. E. (1979). Construct validity of the SAT across populations-An empirical confirmatory study. ETS Research Report Series, 1979(1).

[25] Başusta, N. B., \& Gelbal, S. (2015). Examination of Measurement Invariance at Groups' Comparisons: A Study on PISA Student Questionnaire. Hacettepe Üniversitesi Eğitim Fakültesi Dergisi (HU Journal of Education, 30(4), 80-90.

[26] Byrne, B. M. (1989). Multi-group comparisons and the assumption of equivalent construct validity across groups: Methodological and substantive issues. Multivariate Behavioral Research, 24(4), 503-523.

[27] Kalender, İ. (2015). Measurement Invariance of Student Evaluation of Teaching across Groups defined by Course-Related Variables. International Online Journal of Educational Sciences, 7(4).

[28] Aydin, S. and Çelik, D. (2017). İlköğretim Matematik Öğretmeni Adaylarının Mesleği Tercih için Güdülenmeleri: Ölçek Geçerlik ve Güvenirlik Çalışması. Bartin Journal of Faculty of Education, 6(2), 783-803.

[29] Vandenberg, R. J., \& Lance, C. E. (1998). A summary of the issues underlying measurement equivalence and their implications for interpreting group differences. In 1998 Research Methods Forum (No. 3, pp. 1-10).

[30] Tabachnick, B. G., \& Fidell, L. S. (2007). Using multivariate statistics (5th ed.). Boston: Allyn and Bacon. 
[31] Lloyd, J., Bond, F. W. \& Flaxman, P. (2017). WorkRelated Self-Efficacy as a Moderator of the Impact of a Worksite Stress Management Training Intervention: Intrinsic Work Motivation as a Higher Order Condition of Effect. Journal of Occupational Health Psychology, 22(1), pp. 115-127.

[32] Friedman, I. A. (2016). Being a teacher: altruistic and narcissistic expectations of pre-service teachers. Teachers and Teaching, 22(5), 625-648.

[33] Kaya, E. ve Yıldırım, T. (2015). Fen Fakültesi Biyoloji Bölümü Öğrencilerinin Gözüyle Öğretmenlik. Bayburt Eğitim Fakültesi Dergisi, 10(2).

\section{BIOGRAPHIES}

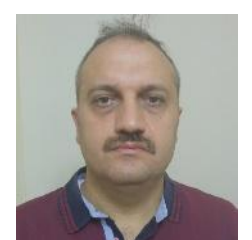

Aydın, S. has obtained his Ph.D. degree from Karadeniz Technical University, Turkey (2014). His areas of interest are teacher education, beliefs, attitudes, and pedagogical content knowledge.

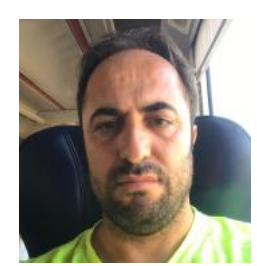

YAZAR M. İ. has obtained his Phd degree - Mathematics from Yüzüncü Yil University, Turkey (2014). His areas of interest are Soft set theory, fuzzy set theory, decision making problems. 